\title{
Synthesis of new Bismuth (III) compound and adducts of benzothiazol disulfide derivatives and their complexes with $\mathrm{Co}(\mathrm{II}), \mathrm{Ni}(\mathrm{II})$ and $\mathrm{Cu}(\mathrm{II})$
}

\author{
Nabeel. H. Buttrus \\ Department of Chemistry \\ College of Scinece
}

\author{
Z. U. Jassim \\ Pharmacetical Science Dept., \\ Pharmacy College \\ Mosul University
}

Received

$05 / 12$ / 2007
Accepted

03 / 03 / 2008

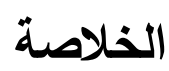

يتفاعل فلز البزموث مع ثنائي بنزوناي ازول ثنائي الكبريتيد

ليعطي المركب Bi( البزموث و

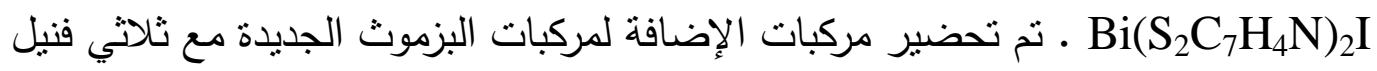

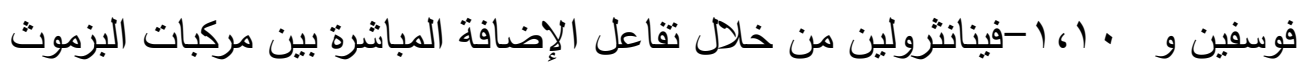

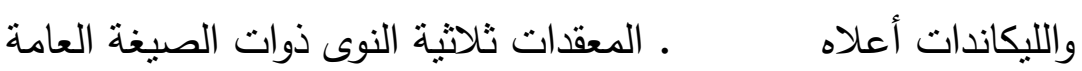
ت مباشر ما بين

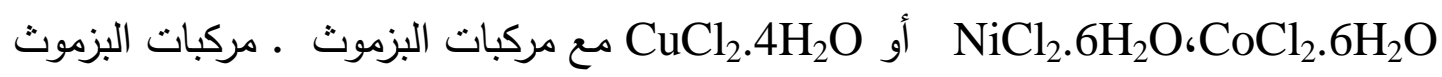
ومركبات الإضافة والمعقدات نم تثخيصها بالطرق الفيزياوية والكيمياوية وبالطرق الطيفية.

\section{Abstract}

Bismuth metal react with dibenzothiazole disulfide $\left(\mathrm{C}_{7} \mathrm{H}_{4} \mathrm{NS}_{2}\right)_{2}$ in refluxing toluene to give the compound $\mathrm{Bi}\left(\mathrm{S}_{2} \mathrm{C}_{7} \mathrm{H}_{4} \mathrm{~N}\right)_{3}$ through oxidative addition reaction, similary, a mixture of bismuth, $\left(\mathrm{C}_{7} \mathrm{H}_{4} \mathrm{NS}_{2}\right)_{2}$ and iodine in 1:1:0.5 molar ratio in refluxing toluene lead to the formation of $\mathrm{Bi}\left(\mathrm{S}_{2} \mathrm{C}_{7} \mathrm{H}_{4} \mathrm{~N}\right)_{2}$ I. Adducts of new bismuth compounds with triphenylphosphine and 1,10-phenanthroline have been synthesized by direct reaction between the bismuth compounds and the neutral ligand. Trinuclear complexes of the general formula $\left[\mathrm{Bi}\left(\mathrm{S}_{2} \mathrm{C}_{7} \mathrm{H}_{4} \mathrm{~N}\right)_{3}\left(\mathrm{MCl}_{2}\right)_{2}\right]$ were prepared by a direct reaction of $\mathrm{CoCl}_{2} \cdot 6 \mathrm{H}_{2} \mathrm{O}, \mathrm{NiCl}_{2} \cdot 6 \mathrm{H}_{2} \mathrm{O}$ or $\mathrm{CuCl}_{2} \cdot 4 \mathrm{H}_{2} \mathrm{O}$ with bismuth compound. The bismuth compounds their adducts and the complexes have been characterized physico-chemically and spectroscopically. 


\section{Introduction}

The past decade has seen a period of intense activity in study of the complexation of transition metal and main group metal ions with thioether ligands ${ }^{(1-4)}$.

Coordinated thiolato sulfur atoms tend to make bridges with a variety of metal ions, and considerable attention has been focused on the S-bridged polynuclear structure derived from [M(thiolato-S $\left.)_{2}(\text { amine- } \mathrm{N})_{2}\right]-$ type $(\mathrm{M}=\mathrm{Ni}(\mathrm{II}), \mathrm{Pd}(\mathrm{II})]$ mononuclear complexes ${ }^{(5-8)}$.

The synthesis of dihalobis (2-pyridinethiolato) tin(IV) by an oxidative addition reaction of di-2-pyridyldisulfide to tin (II) halides represents an example of preparing other similar dihalodithiolato tin(IV) compounds $^{(9)}$. In our previous studies ${ }^{(10,11)}$ we have describe a direct reaction between bismuth or tin metal with $\left(\mathrm{RC}_{6} \mathrm{H}_{4} \mathrm{~S}\right)_{2},\left(\mathrm{R}=o-\mathrm{NH}_{2}, p-\mathrm{Me}\right.$, $p$-Bu.t) refluxing toluene to give the corresponding comounds $\mathrm{Bi}\left(\mathrm{SC}_{6} \mathrm{H}_{4} \mathrm{R}\right)_{3}$ and $\mathrm{Sn}\left(\mathrm{SC}_{6} \mathrm{H}_{4} \mathrm{R}\right)_{4}$ respectively.

Trinuclear complexes of the general formula $\left[\mathrm{Sn}\left(\mathrm{SC}_{6} \mathrm{H}_{4} \mathrm{NH}_{2}-\mathrm{o}\right)_{4}\right.$ $\left.\left(\mathrm{MCl}_{2}\right)_{2}\right)\{\mathrm{M}=\mathrm{Ni}(\mathrm{II}), \mathrm{Pd}(\mathrm{II})$ or $\mathrm{Pt}(\mathrm{II})\}$ were prepared by a direct reaction of $\mathrm{NiCl}_{2} \cdot 6 \mathrm{H}_{2} \mathrm{O}, \mathrm{Na}_{2} \mathrm{PdCl}_{4}$ or $\mathrm{K}_{2} \mathrm{PtCl}_{4}$ with the tin compound ${ }^{(12)}$.

In view of these interesting results and as continuation of our studies on transition and non-transition metal complexes with sulfurcontaining ligands ${ }^{(13-15)}$ we have prepared the bismuth compound $\mathrm{Bi}\left(\mathrm{S}_{2} \mathrm{C}_{7} \mathrm{H}_{4} \mathrm{~N}\right)_{3}$, also, the derivatives with iodine and their adducts with neutral ligands, as well as the trinuclear complexes of general formula $\left[\mathrm{Bi}\left(\mathrm{S}_{2} \mathrm{C}_{7} \mathrm{H}_{4} \mathrm{~N}\right)_{3}\left(\mathrm{MCl}_{2}\right)_{2}\right]$.

\section{Experimental}

\section{General}

IR spectra were recorded on Tensor 27 Co.Brucker (FT.IR) Spectrophotometer in the $\left(4000-250 \mathrm{~cm}^{-1}\right)$ range using Nujol mulls or CsI disc. The metal content was estimated spectrophotometarically using Shimadzu AA670. Conductivity measurements were made on $10^{-3} \mathrm{M}$ solution of the complexes in dimethylsulfoxide (DMSO) solvent at ambient temperature using conductivity meter model 4070 Jenway. Electronic spectra were recorded on Shimadzu UV/Vis. Spectrophotometer UV-160 for $10^{-3} \mathrm{M}$ solution of the complexes in DMSO using $1 \mathrm{~cm}$ quartz cell. The magnetic measurements were carried out at $25^{\circ} \mathrm{C}$ on the solid by Faraday's method using Burker BM6 instrument.

\section{Starting material}

Bismuth metal, toluene and dibenzothiazoldisulfide were commercial products (Fluka) and used as supplied. 


\section{Preparation of Bismuth (III) compounds.}

1- $\mathbf{B i}\left(\mathbf{S}_{2} \mathbf{C}_{7} \mathbf{H}_{4} \mathbf{N}_{2}\right)_{3}$. Finely cut bismuth metal $(0.21 \mathrm{~g}, 1.0 \mathrm{mmol})$ and the disulfide $\left(\mathrm{S}_{2} \mathrm{C}_{7} \mathrm{H}_{4} \mathrm{~N}\right)_{2}(0.48 \mathrm{~g}, 1.5 \mathrm{mmol})$ in toluene $\left(30 \mathrm{~cm}^{3}\right)$ was refluxed for $8 \mathrm{~h}$. The reaction mixture was filtered through celite and the resultant solution was reduced to ca $10 \mathrm{~cm}^{3}$, of its volume by evaporation under reduced pressure. The solid thus obtained after cooling in an ice-bath, was collected by filtration, washed with peteroleum ether $\left(60-80^{\circ} \mathrm{C}\right)$ and dried in vacuo.

2- $\mathbf{B i}\left(\mathbf{S}_{\mathbf{2}} \mathbf{C}_{7} \mathbf{H}_{\mathbf{4}} \mathbf{N}\right)_{2} \mathbf{I}$. Finely cut bismuth metal $(0.21 \mathrm{~g}, 1.0 \mathrm{mmol})$ was refluxed with the disulfide $(0.33 \mathrm{~g}, 1.0 \mathrm{mmol})$ and iodine $(0.064 \mathrm{~g}$, $0.50 \mathrm{mmol})$ in toluene $\left(30 \mathrm{~cm}^{3}\right)$ for $4 \mathrm{~h}$. The reaction mixture was filtered through celite and the resultant brown solution was reduced to ca $10 \mathrm{~cm}^{3}$ of its volume by evaporation under reduced pressure. The solid thus obtained after cooling in an ice-bath, was collected by filtration, washed with peteroleum ether $\left(60-80^{\circ} \mathrm{C}\right)$ and dried in vacuo.

\section{Preparation of $\mathrm{Bi}\left(\mathrm{S}_{2} \mathrm{C}_{7} \mathrm{H}_{4} \mathrm{~N}_{2}\right)_{3}$ adducts:}

3- $\mathbf{B i}\left(\mathbf{S}_{\mathbf{2}} \mathbf{C}_{7} \mathbf{H}_{\mathbf{4}} \mathbf{N}_{2}\right)_{3}$.2PPh $\mathbf{P P}_{3}$. The bismuth compound $\mathrm{Bi}\left(\mathrm{S}_{2} \mathrm{C}_{7} \mathrm{H}_{4} \mathrm{~N}_{2}\right)_{3}(0.49 \mathrm{~g}$, 10. mmol) was added to a solution of the ligand $\mathrm{PPh}_{3}(0.52 \mathrm{~g}, 2.0$ mmol) in ethanol $\left(20 \mathrm{~cm}^{3}\right)$ at room temperature. The reaction mixture was stirred for $4 \mathrm{~h}$., during which time a precipitate formed. It was collected by filtration, washed with ethanol, diethylether and dried in vacuo.

4- $\mathbf{B i}\left(\mathbf{S}_{2} \mathbf{C}_{7} \mathbf{H}_{\mathbf{4}} \mathbf{N}_{2}\right)_{3}$. Phen. The bismuth compound $\mathrm{Bi}\left(\mathrm{S}_{2} \mathrm{C}_{7} \mathrm{H}_{4} \mathrm{~N}_{2}\right)_{3}(0.49 \mathrm{~g}$, 10. mmol) was stirred with 1,10 -phenantholine $(0.18 \mathrm{~g}, 1.0 \mathrm{mmol})$ in benzen $\left(20 \mathrm{~cm}^{3}\right)$ for ca $2 \mathrm{~h}$., during which time a dark yellow oily layer was separated from the colourless solution and colourless layer was decanted. The oily layer was triturated with diethylether $\left(30 \mathrm{~cm}^{3}\right)$ until it solidified and the resultant yellow solid was filtered, washed with ether and dried in vacuo.

The analogous adducts $\mathrm{Bi}\left(\mathrm{S}_{2} \mathrm{C}_{7} \mathrm{H}_{4} \mathrm{~N}_{2}\right)_{2} \mathrm{I} \cdot 2 \mathrm{PPh}_{3}(5)$ or $\mathrm{Bi}\left(\mathrm{S}_{2} \mathrm{C}_{7} \mathrm{H}_{4} \mathrm{~N}_{2}\right)_{2} \mathrm{I}$. Phen (6) were prepared similarly.

\section{Preprartion of $\left[\mathrm{Bi}\left(\mathrm{S}_{2} \mathrm{C}_{7} \mathrm{H}_{4} \mathbf{N}_{2}\right)_{3}\left(\mathrm{MCl}_{2}\right)_{2}\right]$ complexes}

$\mathrm{M}=\mathrm{Co}(\mathrm{II}), \mathrm{Ni}(\mathrm{II}), \mathrm{Cu}(\mathrm{II})$

A clear solution of $\mathrm{Bi}\left(\mathrm{S}_{2} \mathrm{C}_{7} \mathrm{H}_{4} \mathrm{~N}_{2}\right)_{3}(0.49 \mathrm{~g}, 10 . \mathrm{mmol})$ in methanol $\left(10 \mathrm{~cm}^{3}\right)$ was added to a solution of $\mathrm{CoCl}_{2} \cdot 6 \mathrm{H}_{2} \mathrm{O}$ or $\mathrm{NiCl}_{2} \cdot 6 \mathrm{H}_{2} \mathrm{O}$ or $\mathrm{CuCl}_{2} \cdot 6 \mathrm{H}_{2} \mathrm{O}(2.0 \mathrm{mmol})$ in distilled water $\left(10 \mathrm{~cm}^{3}\right)$. The mixture was stirred under reflux for ca. $2 \mathrm{~h}$. the formed precipitate, was filtered off washed with methanol, and diethylether then dried under vacuo. 


\section{Results and Discussion}

The direct reaction of the ligand dibenzothiazole disulfide with bismuth metal in refluxing toluene using a 1:2 metal to ligand molar ratio afforded the compound $\mathrm{Bi}\left(\mathrm{S}_{2} \mathrm{C}_{7} \mathrm{H}_{4} \mathrm{~N}_{2}\right)_{3}$ through an oxidative addition reaction ${ }^{(15)}$, also the reaction of iodine with disulfide and bismuth metal give a product of the formula $\mathrm{Bi}\left(\mathrm{S}_{2} \mathrm{C}_{7} \mathrm{H}_{4} \mathrm{~N}_{2}\right)_{2} \mathrm{I}$. The mechanism of these reactions involves the initial cleavage of the $-\mathrm{S}-\mathrm{S}-$ bond to form the thiolate ion and the oxidation of bismuth metal from $\mathrm{Bi}^{0}$ to $\mathrm{Bi}^{+3}$. The reaction of the above compounds with neutral ligands were also reported. Treatment of the bismuth compound in alcohol with aqueous solution of metal chloride in (1:2) molar ratio gave the trinuclear complexes of the type $\left[\mathrm{Bi}\left(\mathrm{S}_{2} \mathrm{C}_{7} \mathrm{H}_{4} \mathrm{~N}_{2}\right)_{3}\left(\mathrm{MCl}_{2}\right)_{2}\right]$. The nucleophilicity of the thiolate sulfur atoms in the bismuth compound is responsible for the formation of these new complexes. The physical properties of the compounds and complexes are listed in (Table 1).

The complexes are quite stable in dry air and melt or decompose at above than $135{ }^{\circ} \mathrm{C}$. They are insoluble in most organic solvents but soluble in dimethylformamide.

The most important IR assignment of bismuth compounds and their complexes are listed in Table 2. The infrared spectra of the ligand showed a sharp band at $1021 \mathrm{~cm}^{-1}$ attributed to $\mathrm{C}-\mathrm{S}$ stretching vibration, which shifts to lower value in the compounds, indicating a coordination between sulfur and bismuth ${ }^{(16)}$, strong band in the $1580 \mathrm{~cm}^{-1}$ region, while were assigned to $v(\mathrm{C}=\mathrm{N})$, the negligible effect on this frequency after complexation precludes the possibility of sharing of this group. Furthermore, the IR spectra of the adducts with $\mathrm{PPh}_{3}$ and Phen show a medium band at 985-990 $\mathrm{cm}^{-1}$ indicating that the ligand coordinated through sulphur atoms. Further support for this was obtained from the appearance of a new band at $323-336 \mathrm{~cm}^{-1}$ which assigned $v(\mathrm{Bi}-\mathrm{S})$ while the $v(\mathrm{Bi}-\mathrm{N})$ and $v(\mathrm{Bi}-\mathrm{P})$ for 1,10-phenanthroline and triphenylphosphine are in good agreement with the reported values of In.X $X_{3} .1 .5$ phen $(\mathrm{X}=\mathrm{Cl}, \mathrm{Br})$ which fall in the $410-450 \mathrm{~cm}^{-1}$, while the $v(\mathrm{Bi}-\mathrm{P})$ band is abserved at $480-510 \mathrm{~cm}^{-1}$ similar results was found some were else $\mathrm{s}^{(18)}$. The frequency of $v(\mathrm{C}-\mathrm{S})$ band observed at to $995-1005 \mathrm{~cm}^{-1}$ in the compounds is slightly decreased upon complexation with $\mathrm{MCl}_{2}$ to form the corresponding trinuclear complexes. Further support for the formation of new complexes is provided by the appearance of a new band at 340$380 \mathrm{~cm}-1$ range characteristic of bidentate trithiobismuth ${ }^{(17)}$, as shown below.

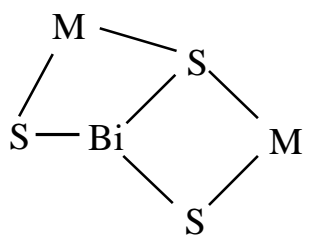


The electronic spectrum of the ligand contains three absorption bands in 38700,33222 and $28818 \mathrm{~cm}^{-1}$ (Table 2) which may be assigned as $\mathrm{n} \longrightarrow \pi^{*}$ or $\pi-\pi^{*}$ transitions respectively. The U.V spectral bands of the ligand were observed at higher region upon formation of compounds and their adducts which were observed in 36910-21809 $\mathrm{cm}^{-1}$ ranges, indicating that the bonding of the ligand with the metal ion through sulphur, nitrogen or phosphorus atoms ${ }^{(19)}$.

The values of magnetic moment of Co(II) complex(7) is 2.01 B.M. this value correspond to low spin square planar geometry for the comple $^{(20)}$. The electronic spectra of $\mathrm{Co}$ (II) complex show a bands at $15797 \mathrm{~cm}^{-1}$, which may be assigned to ${ }^{2} \mathrm{~A}_{1} \mathrm{~g} \longrightarrow{ }^{2} \mathrm{Eg}$ transition in square planer geometry and $26525 \mathrm{~cm}^{-1}$ which may be assigned as charge transfer.

The Ni(II) complex (8) was diamagnetic and its electronic spectra showed two bands (Table 2). These bonds were assigned to ${ }^{1} \mathrm{~A}_{1} \mathrm{~g} \longrightarrow{ }^{1} \mathrm{~B}_{2} \mathrm{~g}$ and ${ }^{1} \mathrm{~A}_{1} \mathrm{~g} \longrightarrow{ }^{1}$ Eg transition respectively. These results suggest a square planer geometry around the nickel ion ${ }^{(21)}$.

$\mathrm{The} \mathrm{Cu}(\mathrm{II})$ complex (9) shows a magnetic moment of 2.01 B.M. the electronic spectrum showed broad band centered at $13600 \mathrm{~cm}^{-1}$ correspond to the transition ${ }^{2} \mathrm{~B}_{1} \mathrm{~g} \longrightarrow{ }^{2} \mathrm{~A}_{1} \mathrm{~g}$ for distorted square planer geometry around $\mathrm{Cu}(\mathrm{II})^{(20)}$.

From the above discussion, the following structures can be suggested for the compounds and the complexes. 


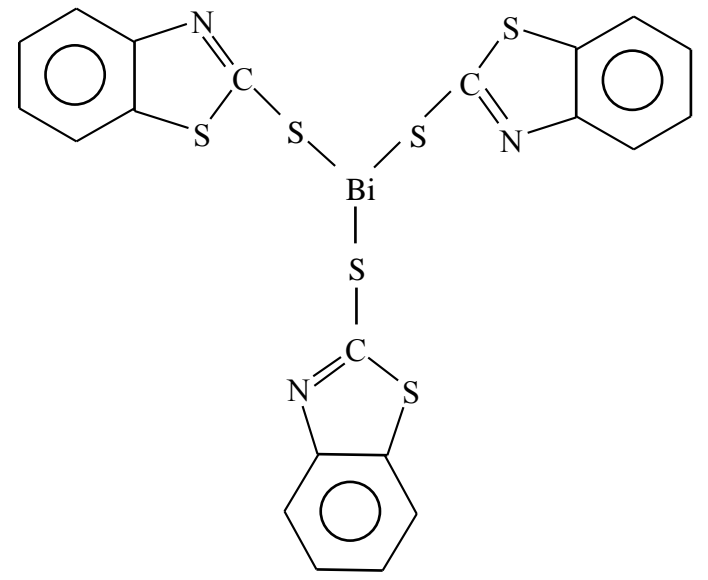

(1)

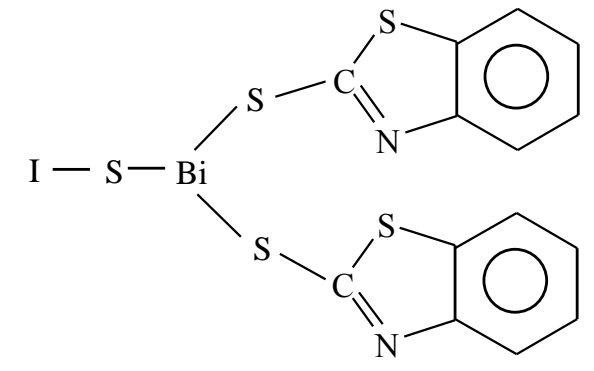

(4)

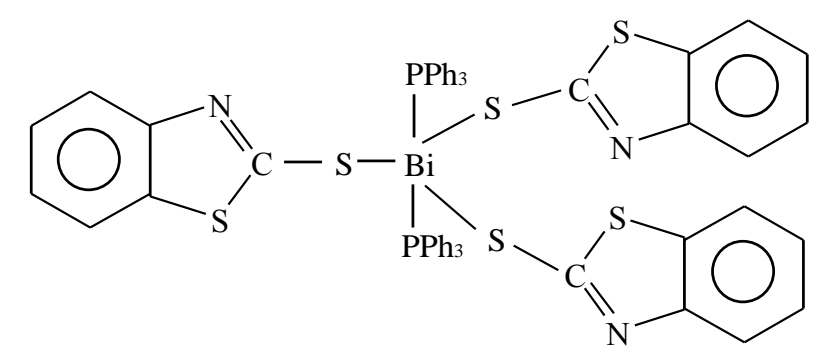

(3)

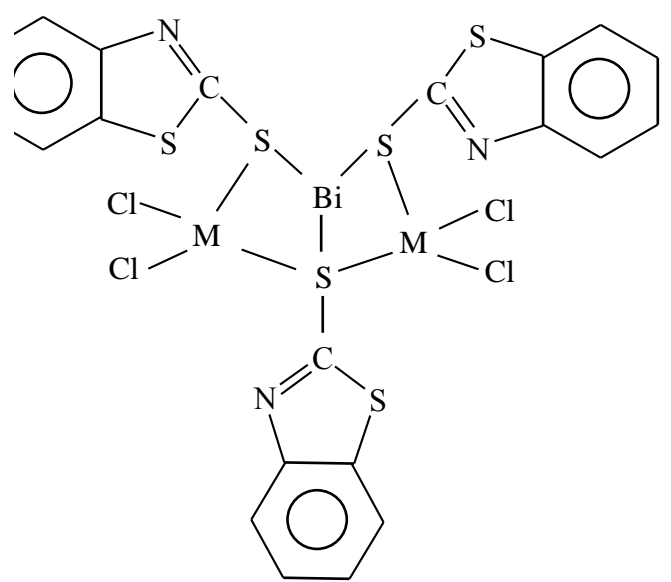

(7-9)

$$
\mathrm{M}=\mathrm{Co}(\mathrm{II}), \mathrm{Ni}(\mathrm{II}) \text { or } \mathrm{Cu}(\mathrm{II})
$$

Fig 1: Suggested structures for the prepared compounds ,adducts and complexes 
Nabeel. H. Buttrus \& Z. U. Jassim

Table 1: Physical properties of compounds and complexes

\begin{tabular}{|c|c|c|c|c|c|c|c|c|}
\hline \multirow[t]{2}{*}{ No. } & \multirow[t]{2}{*}{ compound } & \multirow[t]{2}{*}{ colour } & \multirow{2}{*}{$\begin{array}{l}\text { Yield } \\
\%\end{array}$} & \multirow{2}{*}{$\begin{array}{l}\text { M.p } \\
\left({ }^{\circ} \mathrm{C}\right)\end{array}$} & \multicolumn{2}{|c|}{$\begin{array}{l}\text { Analysis \% } \\
\text { Found(calc.) }\end{array}$} & \multirow[t]{2}{*}{$\boldsymbol{\mu}_{e f f}$} & \multirow{2}{*}{$\begin{array}{c}\Omega \\
\text { ohm }^{1} \cdot \mathrm{cm}^{2} \\
\mathrm{~mol}^{-1} \\
\end{array}$} \\
\hline & & & & & $\mathrm{Bi}$ & $\mathrm{M}$ & & \\
\hline 1 & $\mathrm{Bi}\left(\mathbf{S}_{2} \mathbf{C}_{7} \mathbf{H}_{4} \mathbf{N}\right)_{3}$ & Yellow & 94 & 184 & $\begin{array}{c}29.48 \\
(29.56)\end{array}$ & --- & --- & 10 \\
\hline 2 & $\mathrm{Bi}\left(\mathrm{S}_{2} \mathrm{C}_{7} \mathbf{H}_{4} \mathbf{N}\right)_{3} \cdot($ phen $)$ & $\begin{array}{l}\text { Olive } \\
\text { yellow }\end{array}$ & 85 & 149 & & --- & --- & 35 \\
\hline 3 & $\mathbf{B i}\left(\mathbf{S}_{2} \mathrm{C}_{7} \mathrm{H}_{4} \mathbf{N}\right)_{3 \cdot} \cdot\left(2 \mathrm{PPh}_{3}\right)$ & Brown & 88 & $198^{\mathrm{d}}$ & & $-\cdots$ & $-\cdots$ & 60 \\
\hline 4 & $\mathrm{Bi}\left(\mathrm{S}_{2} \mathrm{C}_{7} \mathrm{H}_{4} \mathrm{~N}\right)_{3} \cdot \mathrm{I}$ & Maroon & 70 & $157^{\mathrm{d}}$ & $\begin{array}{l}31.20 \\
(31.28)\end{array}$ & --- & --- & 29 \\
\hline 5 & $\mathbf{B i}\left(\mathbf{S}_{2} \mathbf{C}_{7} \mathbf{H}_{4} \mathbf{N}\right)_{3 .}$.I.(phen) & $\begin{array}{c}\text { Dark } \\
\text { brown }\end{array}$ & 87 & $115^{\mathrm{d}}$ & & --- & --- & 70 \\
\hline 6 & $\mathrm{Bi}\left(\mathrm{S}_{2} \mathrm{C}_{7} \mathrm{H}_{4} \mathrm{~N}\right)_{3} . \mathrm{I} .\left(2 \mathrm{PPh}_{3}\right)$ & $\begin{array}{l}\text { Brown } \\
\text { yellow }\end{array}$ & 65 & 132 & & --- & -- & 30 \\
\hline 7 & {$\left[\mathrm{Bi}\left(\mathrm{S}_{2} \mathrm{C}_{7} \mathrm{H}_{4} \mathbf{N}\right)_{3 \cdot}\left(\mathrm{CoCl}_{2}\right)_{2}\right]$} & $\begin{array}{l}\text { Dark } \\
\text { green }\end{array}$ & 70 & $183^{d}$ & $\begin{array}{c}21.64 \\
(21.61)\end{array}$ & $\begin{array}{c}12.40 \\
(12.19)\end{array}$ & 2.10 & 40 \\
\hline 8 & {$\left[\mathrm{Bi}\left(\mathrm{S}_{2} \mathrm{C}_{7} \mathbf{H}_{4} \mathbf{N}\right)_{3 \cdot} \cdot\left(\mathrm{NiCl}_{2}\right)_{2}\right]$} & Brown & 64 & $162^{d}$ & $\begin{array}{l}21.59 \\
(21.61)\end{array}$ & $\begin{array}{c}12.11 \\
(12.18)\end{array}$ & Dia & 35 \\
\hline 9 & {$\left[\mathrm{Bi}\left(\mathrm{S}_{2} \mathrm{C}_{7} \mathrm{H}_{4} \mathrm{~N}\right)_{3 \cdot}\left(\mathrm{CuCl}_{2}\right)_{2}\right]$} & $\begin{array}{l}\text { Pale } \\
\text { olive }\end{array}$ & 91 & $202^{d}$ & $\begin{array}{c}21.32 \\
(21.41) \\
\end{array}$ & $\begin{array}{c}12.99 \\
(12.01) \\
\end{array}$ & 2.01 & 32 \\
\hline
\end{tabular}

$\mathrm{d}=$ decomposition

Table 2: Infrared and electronic data for compounds and adducts

\begin{tabular}{|c|c|c|c|c|c|c|c|}
\hline No. & & & $\mathrm{R}$ band assign & ments (cm & & & UV.Visible \\
\hline & $v(C-S)$ & $v(C=N)$ & $v(M-S)$ & $v(M-N)$ & $v(M-P)$ & $\mathrm{v}(\mathrm{M}-\mathrm{Cl})$ & band $\lambda_{\max }\left(\mathrm{cm}^{-1}\right)$ \\
\hline 1 & $1001_{\mathrm{S}}$ & $1580 \mathrm{~m}$ & $329_{\mathrm{m}}$ & --- & ---- & ---- & 259741,33112 \\
\hline 2 & $1005_{\mathrm{S}}$ & $1582 \mathrm{~m}$ & $332_{\mathrm{m}}$ & $410_{m}$ & ---- & ---- & 28089,31948 \\
\hline 3 & $1000_{\mathrm{S}}$ & $1579 \mathrm{~m}$ & $335_{\mathrm{m}}$ & ---- & $480_{m}$ & ---- & 27624,32679 \\
\hline 4 & $985_{S}$ & $1582 \mathrm{~m}$ & $322_{\mathrm{m}}$ & $\begin{array}{ll}--- \\
\end{array}$ & ---- & ---- & 24573,34129 \\
\hline 5 & $989_{\mathrm{S}}$ & $1580 \mathrm{~m}$ & $325_{\mathrm{m}}$ & $450_{\mathrm{m}}$ & $\begin{array}{ll}--- \\
\end{array}$ & ---- & 27777,31654 \\
\hline 6 & $990_{S}$ & $1585 \mathrm{~m}$ & $330_{\mathrm{m}}$ & ---- & $510_{\mathrm{m}}$ & ---- & 27472,33898 \\
\hline 7 & $995_{S}$ & $1580 \mathrm{~s}$ & 330,380 & ---- & ---- & 300 & $15797,26525,30211$ \\
\hline 8 & $998_{S}$ & $1583 \mathrm{~s}$ & 335,375 & ---- & ---- & 310 & $15948,25510,31347$ \\
\hline 9 & $994_{S}$ & $1580 \mathrm{~m}$ & $320,360,380$ & ---- & ---- & 315 & 13600,34722 \\
\hline
\end{tabular}

$\mathrm{s}=$ strong, $\mathrm{m}=$ medium 


\section{References}

1. Holloway, C. E. and Mclnik M., Main Group. Met.Chem., 17, 799, (1994).

2. Pickard, J. and Shen, J., Z. Naturforsch., B48,969, (1993).

3. Gevantes G., Moreno V., Molins E. and Miravitlles, C., Metal Based Drugs, 6(4), 317,(1997).

4. Ivanov A. V., Rodyna T. A. and Antzutkin, Polyhedron, 17(18), 3101, (1998).

5. Tuntulani T., Reibenspies J. H., Farmer P. J. and Darensbourg M. Y., Inorg. Chem., 31, 3497, (1992).

6. Kang D., Poor M., Blinn E. L. and Trichel P. M., Inorg. Chim. Acta, 168, 209, (1990).

7. Huang Y., Drake R. J. and Stephan D. W., Inorg. Chem., 32, 3022, (1993).

8. Kono T., Yonenobu K., Hidaka J. and Okamoto K. I., Inorg. Chem., 33(5), 861, (1994).

9. Masaki M. and Matsunami S., Bull. chem. Soc. Jpn., 49, 3274, (1978).

10. Buttrus. N. H., Synth. React. Inorg. Met-Org. Chem., 28, 1643, (1998).

11. Buttrus N. H., Suliman M. M. and AL-Allaf J. A. K., Synth. React. Inorg. Met-Org. Chem., 31(5), 837, (2001).

12. AL-Haylay J. L., Buttrus N. H., Tarq F. and AL-Allaf T. A. K., J. J. Appl. Sci., 7(1), 64, (2005).

13. Buttrus N. H., National J. Chem., 8, 611, (2002).

14. Buttrus N. H., Jasim Z. U. and AL-Allaf T. A. K., J. J. Appl. Sci., 7(2), 92, (2005).

15. Buttrus N. H., AL-Razaq E. A. and AL-Sger A.K., Int. J. Chem. Sci., 5(3), 1111, (2007).

16. Haiduc I. and Goh L. Y., Coord. Chem.Rev., 224, 151, (2002).

17. Tiekink E. R. T., Cryst. Eng. Commn., 5(21), 101, (2003).

18. Roundhil D. M., J. Inorg. Nucl. Chem., 81, 7, (1970).

19. Buttrus N. H., Saied F. T. and Zeedan S. W., J. Educ. Sci., 19(4), 14, (2007).

20. Buttrus N. H. and Mohamed E., Raf. J. Sci., 17(4), 15, (2006).

21. Trifunovic S. R., Markovic Z., Saldic D., Andjelkovic K., Sabo T. and Miuic D., J. Serb. Chem. Soc., 67(2), 115, (2002). 